\title{
Calcified Specimen
}

National Cancer Institute

\section{Source}

National Cancer Institute. Calcified Specimen. NCI Thesaurus. Code C78723.

A specimen that has undergone calcification. 